\title{
Viscosity $B$ Coefficients of Some Tetraalkylammonium Bromides, Lithium Tetrafluoroborate and Tetrabutylammonium Tetraphenyl borate in Propylene Carbonate
}

\author{
Prakash K. Muhuri and Dilip K. Hazra \\ Department of Chemistry, North Bengal University, 734430 Darjeeling, India
}

Z. Naturforsch. 48a, 523-528 (1993); received September 2, 1992

\begin{abstract}
The viscosities of solutions of tetraalkylammonium bromides, $\mathrm{R}_{4} \mathrm{NBr}\left(\mathrm{R}=-\mathrm{C}_{2} \mathrm{H}_{5}\right.$ to $\left.-\mathrm{C}_{7} \mathrm{H}_{15}\right)$, lithium tetrafluoroborate $\left(\mathrm{LiBF}_{4}\right)$ and tetrabutylammonium tetraphenylborate $\left(\mathrm{Bu}_{4} \mathrm{NBPh}_{4}\right)$ in propylene carbonate $(\mathrm{PC})$ have been measured at 25,35 and $45^{\circ} \mathrm{C}$. The relative viscosities have been analyzed using the Jones-Dole equation in the form of unassociated electrolytes, and the viscosity B-coefficients have been evaluated. The thermodynamic parameters have been calculated using the transition-state treatment and the measured temperature dependencies. Ionic $B$ values have also been derived and discussed in terms of Einstein's equation. The analysis shows that $\mathrm{Li}^{+}$is highly solvated compared to other cations and anions in this medium.
\end{abstract}

\section{Introduction}

Recently we have reported [1] the results of conductance measurements on $\mathrm{LiBF}_{4}$ and tetraalkylammonium bromides in propylene carbonate (PC) at $25^{\circ} \mathrm{C}$. These salts have been found to be almost unassociated in this solvent of a moderately high dielectric constant $\left(64.40\right.$ at $\left.25^{\circ} \mathrm{C}\right)$. Single ion mobilities were also derived and discussed in terms of the ion solvating ability of PC.

We have now extended this work to study the viscometric behaviour of these electrolytes at different temperatures to obtain more information about specific ion-solvent interactions in this solvent. Ionic $B$ values have been derived on the basis of the reference electrolyte " $\mathrm{Bu}_{4} \mathrm{NBPh}_{4}$ ", and the transition-state treatment has been applied to analyse the results.

\section{Experiental}

Propylene carbonate (E. Merck, Germany, $>99 \%$ pure) was purified according to the procedure described previously [1]. The solvent properties have been recorded in Table 1.

The purification of tetraalkylammonium bromides, $\mathrm{LiBF}_{4}$ and $\mathrm{Bu}_{4} \mathrm{NBPh}_{4}$ have been reported earlier [1].

The concentrations of the salts, generally varying in the range of $0.01-0.08 \mathrm{~mol} \mathrm{dm}^{-3}$, were prepared by

Reprint requests to Dr. D. K. Hazra, Department of Chemistry, North Bengal University, 734430 Darjeeling, India. weight dilution of the stock solution (ca. $0.1 \mathrm{~mol} \mathrm{~kg}^{-1}$ ). The conversion of the molality into molarity was done by using the density values. The kinematic viscosities were measured at the desired temperature (accuracy $\pm 0.01{ }^{\circ} \mathrm{C}$ ) using a suspended Ubbelohde-type viscometer. The densities were measured using an OstwaldSprengel type pycnometer $(25 \mathrm{ml})$ calibrated with distilled water. The details of the experimental procedure have been described in $[2,3]$. The accuracies of the viscosity and density measurements were $0.05 \%$ and $\pm 3 \times 10^{-5} \mathrm{~g} \mathrm{~cm}^{-3}$, respectively.

\section{Density and Viscosity Data}

The density $(\varrho)$ and viscosity $(\eta)$ data for the electrolytes in the molarity range $0.01-0.08 \mathrm{~mol} \mathrm{dm}^{-3}$ at temperatures 25,35 , and $45^{\circ} \mathrm{C}$ are reported in Table 2 .

\section{Viscosity $A$ and B Coefficients}

The experimental data have been analysed with the Jones-Dole equation [4]

$$
\left(\eta_{\mathrm{r}}-1\right) / \sqrt{C}=A+B \sqrt{C}, \quad \eta_{\mathrm{r}}=\eta / \eta_{0},
$$

Table 1. Solvent properties of propylene carbonate.

\begin{tabular}{llll}
\hline $\begin{array}{l}\text { Temp. } \\
\left({ }^{\circ} \mathrm{C}\right)\end{array}$ & $\begin{array}{l}\text { Density } \\
\left(\mathrm{g} \mathrm{cm}^{-3}\right)\end{array}$ & $\begin{array}{l}\text { Viscosity } \\
(\mathrm{cP})\end{array}$ & $\begin{array}{l}\text { Dielectric } \\
\text { constant }\end{array}$ \\
\hline 25 & 1.19883 & 2.4712 & 64.40 \\
35 & 1.18970 & 2.0476 & 63.41 \\
45 & 1.17796 & 1.7234 & 60.92 \\
\hline
\end{tabular}


Table 2. Concentration, $C /\left(\mathrm{mol} \mathrm{dm}^{-3}\right)$, density, $\varrho /\left(\mathrm{g} \mathrm{cm}^{-3}\right)$ and relative viscosity, $\eta_{\mathrm{r}}$, of tetraalkylammonium bromides, $\mathrm{LiBF}_{4}$ and $\mathrm{Bu}_{4} \mathrm{NBPh}_{4}$ in propylene carbonate at 25,35 and $45^{\circ} \mathrm{C}$.

\begin{tabular}{|c|c|c|c|c|c|c|c|c|c|c|c|}
\hline$C$ & $\varrho$ & $\eta_{\mathrm{r}}$ & $C$ & $\varrho$ & $\eta_{\mathrm{r}}$ & $C$ & $\varrho$ & $\eta_{\mathrm{r}}$ & $C$ & $\varrho$ & $\eta_{\mathrm{r}}$ \\
\hline $\mathbf{E t}_{\mathbf{4}} \mathrm{NBr}$ & $25^{\circ} \mathrm{C}$ & & $\mathrm{Pr}_{4} \mathrm{NBr}$ & $25^{\circ} \mathrm{C}$ & & $\mathrm{Hex}_{4} \mathrm{NBr}$ & $35^{\circ} \mathrm{C}$ & & $\mathrm{Hep}_{4} \mathrm{NBr}$ & $35^{\circ} \mathrm{C}$ & \\
\hline $\begin{array}{l}0.01002 \\
0.01644 \\
0.02506 \\
0.03509 \\
0.04511 \\
0.05514\end{array}$ & $\begin{array}{l}1.19000 \\
1.19910 \\
1.19925 \\
1.19941 \\
1.19957 \\
1.19973\end{array}$ & $\begin{array}{l}1.0081 \\
1.0130 \\
1.0193 \\
1.0266 \\
1.0343 \\
1.0418\end{array}$ & $\begin{array}{l}0.00995 \\
0.02020 \\
0.03015 \\
0.05005 \\
0.06001 \\
0.08020\end{array}$ & $\begin{array}{l}1.19870 \\
1.19856 \\
1.19843 \\
1.19816 \\
1.19803 \\
1.19776\end{array}$ & $\begin{array}{l}1.0096 \\
1.0188 \\
1.0351 \\
1.0452 \\
1.0540 \\
1.0716\end{array}$ & $\begin{array}{l}0.00991 \\
0.02475 \\
0.03958 \\
0.04945 \\
0.06917\end{array}$ & $\begin{array}{l}1.18808 \\
1.18563 \\
1.18318 \\
1.18155 \\
1.17827\end{array}$ & $\begin{array}{l}1.0145 \\
1.0352 \\
1.0558 \\
1.0693 \\
1.0961\end{array}$ & $\begin{array}{l}0.00999 \\
0.02976 \\
0.03974 \\
0.04951 \\
0.05947\end{array}$ & $\begin{array}{l}1.18803 \\
1.18472 \\
1.18303 \\
1.18138 \\
1.17969\end{array}$ & $\begin{array}{l}1.0155 \\
1.0446 \\
1.0584 \\
1.0730 \\
1.0879\end{array}$ \\
\hline $\mathrm{Bu}_{4} \mathrm{NBr}$ & $25^{\circ} \mathrm{C}$ & & $\mathrm{Pen}_{4} \mathrm{NBr}$ & $25^{\circ} \mathrm{C}$ & & $\mathrm{LiBF}_{4}$ & & & $\mathrm{Bu}_{4} \mathrm{NBPh}$ & $\mathrm{h}_{4} \quad 35^{\circ} \mathrm{C}$ & \\
\hline $\begin{array}{l}0.01015 \\
0.01999 \\
0.03076 \\
0.05014 \\
0.05998 \\
0.07997\end{array}$ & $\begin{array}{l}1.19837 \\
1.19792 \\
1.19743 \\
1.19654 \\
1.19609 \\
1.19517\end{array}$ & $\begin{array}{l}1.0116 \\
1.0224 \\
1.0337 \\
1.0538 \\
1.0642 \\
1.0871\end{array}$ & $\begin{array}{l}0.00990 \\
0.02011 \\
0.03001 \\
0.05011 \\
0.06002 \\
0.08012\end{array}$ & $\begin{array}{l}1.19817 \\
1.19749 \\
1.19682 \\
1.19547 \\
1.19480 \\
1.19343\end{array}$ & $\begin{array}{l}1.0130 \\
1.0253 \\
1.0382 \\
1.0619 \\
1.0750 \\
1.0991\end{array}$ & $\begin{array}{l}0.01022 \\
0.02487 \\
0.03987 \\
0.04976 \\
0.05966 \\
0.07947\end{array}$ & $\begin{array}{l}1.19025 \\
1.19104 \\
1.19184 \\
1.19237 \\
1.19290 \\
1.19396\end{array}$ & $\begin{array}{l}1.0125 \\
1.0295 \\
1.0424 \\
1.0572 \\
1.0683 \\
1.0909\end{array}$ & & $\begin{array}{l}1.18873 \\
1.18762 \\
1.18651 \\
1.18490 \\
1.18331\end{array}$ & $\begin{array}{l}1.0141 \\
1.0277 \\
1.0411 \\
1.0621 \\
1.0808\end{array}$ \\
\hline $\mathrm{Hex}_{4} \mathrm{NBr}$ & $25^{\circ} \mathrm{C}$ & & $\mathrm{Hep}_{4} \mathrm{NBr}$ & $25^{\circ} \mathrm{C}$ & & $\mathrm{Et}_{\mathbf{4}} \mathrm{NBr}$ & $45^{\circ} \mathrm{C}$ & & $\mathrm{Pr}_{4} \mathrm{NBr}$ & $15^{\circ} \mathrm{C}$ & \\
\hline $\begin{array}{l}0.00999 \\
0.02498 \\
0.03997 \\
0.04996 \\
0.06994\end{array}$ & $\begin{array}{l}1.19779 \\
1.19621 \\
1.19464 \\
1.19359 \\
1.19149\end{array}$ & $\begin{array}{l}1.0149 \\
1.0368 \\
1.0583 \\
1.0715 \\
1.1017\end{array}$ & $\begin{array}{l}0.01007 \\
0.03002 \\
0.04009 \\
0.04996 \\
0.06003\end{array}$ & $\begin{array}{l}1.19750 \\
1.19485 \\
1.19351 \\
1.19219 \\
1.19084\end{array}$ & $\begin{array}{l}1.0159 \\
1.0458 \\
1.0606 \\
1.0761 \\
1.0904\end{array}$ & $\begin{array}{l}0.00985 \\
0.01616 \\
0.02463 \\
0.03449 \\
0.04435 \\
0.05421\end{array}$ & $\begin{array}{l}1.17827 \\
1.17847 \\
1.17873 \\
1.17904 \\
1.17935 \\
1.17965\end{array}$ & $\begin{array}{l}1.0071 \\
1.0117 \\
1.0174 \\
1.0243 \\
1.0310 \\
1.0374\end{array}$ & $\begin{array}{l}0.00977 \\
0.01985 \\
0.02963 \\
0.04919 \\
0.05897 \\
0.07881\end{array}$ & $\begin{array}{l}1.17785 \\
1.17773 \\
1.17761 \\
1.17737 \\
1.17725 \\
1.17701\end{array}$ & $\begin{array}{l}1.0077 \\
1.0161 \\
1.0241 \\
1.0401 \\
1.0480 \\
1.0640\end{array}$ \\
\hline $\mathrm{LiBF}_{4}$ & $25^{\circ} \mathrm{C}$ & & $\mathrm{BuNBPh}_{4}$ & $25^{\circ} \mathrm{C}$ & & $\mathrm{Bu}_{4} \mathrm{NBr}$ & $15^{\circ} \mathrm{C}$ & & $\mathrm{Pen}_{4} \mathrm{NBr}$ & & \\
\hline $\begin{array}{l}0.01031 \\
0.02508 \\
0.04020 \\
0.05017 \\
0.06013 \\
0.08007\end{array}$ & $\begin{array}{l}1.19937 \\
1.20013 \\
1.20091 \\
1.20142 \\
1.20193 \\
1.20294\end{array}$ & $\begin{array}{l}1.0134 \\
1.0311 \\
1.0503 \\
1.0623 \\
1.0784 \\
1.0975\end{array}$ & $\begin{array}{l}0.00998 \\
0.01997 \\
0.02995 \\
0.04502 \\
0.05990\end{array}$ & $\begin{array}{l}1.19796 \\
1.19708 \\
1.19620 \\
1.19487 \\
1.19356\end{array}$ & $\begin{array}{l}1.0149 \\
1.0293 \\
1.0418 \\
1.0513 \\
1.0844\end{array}$ & $\begin{array}{l}0.00998 \\
0.01966 \\
0.03025 \\
0.04933 \\
0.05903 \\
0.07875\end{array}$ & $\begin{array}{l}1.17707 \\
1.17621 \\
1.17526 \\
1.17355 \\
1.17267 \\
1.17089\end{array}$ & & $\begin{array}{l}0.00972 \\
0.01969 \\
0.02935 \\
0.04885 \\
0.05840 \\
0.0911\end{array}$ & & $\begin{array}{l}1.0120 \\
1.0235 \\
1.0354 \\
1.0574 \\
1.0679 \\
1.0912\end{array}$ \\
\hline $\mathrm{Et}_{\mathbf{4}} \mathrm{NBr}$ & $35^{\circ} \mathrm{C}$ & & $\mathrm{Pr}_{4} \mathbf{N B r}$ & $35^{\circ} \mathrm{C}$ & & $\mathrm{Hex}_{4} \mathrm{NDr}$ & $45 \mathrm{C}$ & & $\mathrm{Hep}_{4} \mathrm{NBr}$ & $45 \mathrm{C}$ & \\
\hline $\begin{array}{l}0.00995 \\
0.01632 \\
0.02487 \\
0.03483 \\
0.04478 \\
0.05473\end{array}$ & $\begin{array}{l}1.18992 \\
1.19006 \\
1.19025 \\
1.19047 \\
1.19069 \\
1.19091\end{array}$ & $\begin{array}{l}1.0077 \\
1.0119 \\
1.0186 \\
1.0248 \\
1.0326 \\
1.0391\end{array}$ & $\begin{array}{l}0.00988 \\
0.02004 \\
0.02992 \\
0.04967 \\
0.05954 \\
0.07958\end{array}$ & $\begin{array}{l}1.18955 \\
1.18938 \\
1.18923 \\
1.18891 \\
1.18875 \\
1.18843\end{array}$ & $\begin{array}{l}1.0089 \\
1.0175 \\
1.0255 \\
1.0425 \\
1.0499 \\
1.0676\end{array}$ & $\begin{array}{l}0.00981 \\
0.02452 \\
0.03921 \\
0.04899 \\
0.06853\end{array}$ & $\begin{array}{l}1.17568 \\
1.17226 \\
1.16884 \\
1.16657 \\
1.16202\end{array}$ & $\begin{array}{l}1.0147 \\
1.0347 \\
1.0546 \\
1.0678 \\
1.0940\end{array}$ & $\begin{array}{l}0.00990 \\
0.02951 \\
0.03942 \\
0.04913 \\
0.05762\end{array}$ & $\begin{array}{l}1.17598 \\
1.17206 \\
1.17007 \\
1.16813 \\
1.16643\end{array}$ & $\begin{array}{l}1.0151 \\
1.0435 \\
1.0585 \\
1.0711 \\
1.0836\end{array}$ \\
\hline $\mathrm{Bu}_{4} \mathrm{NBr}$ & $30 \mathrm{C}$ & & $\mathrm{F}^{-10 \mathrm{NO}}$ & $35^{\circ} \mathrm{C}$ & & $\mathrm{LIOF}_{4}$ & & & $\mathrm{Bu}_{4} \mathrm{NBP}$ & $\mathrm{A}_{4} \quad 45^{\circ} \mathrm{C}$ & \\
\hline $\begin{array}{l}0.01007 \\
0.01983 \\
0.03050 \\
0.04970 \\
0.05945 \\
0.07923\end{array}$ & $\begin{array}{l}1.18898 \\
1.18828 \\
1.18751 \\
1.18612 \\
1.18542 \\
1.18398\end{array}$ & $\begin{array}{l}1.0215 \\
1.0325 \\
1.0523 \\
1.0625 \\
1.0828\end{array}$ & $\begin{array}{l}0.00982 \\
0.01992 \\
0.02918 \\
0.04956 \\
0.05931 \\
0.07968\end{array}$ & $\begin{array}{l}1.18799 \\
1.18622 \\
1.18460 \\
1.18101 \\
1.17929 \\
1.17570\end{array}$ & $\begin{array}{l}1.0125 \\
1.0244 \\
1.0361 \\
1.0587 \\
1.0716 \\
1.0949\end{array}$ & $\begin{array}{l}0.01012 \\
0.02463 \\
0.03951 \\
0.04932 \\
0.05915 \\
0.07882\end{array}$ & $\begin{array}{l}1.17877 \\
1.17992 \\
1.18110 \\
1.18187 \\
1.18265 \\
1.18420\end{array}$ & $\begin{array}{l}1.0117 \\
1.0272 \\
1.0435 \\
1.0538 \\
1.0636 \\
1.0839\end{array}$ & $\begin{array}{l}0.00980 \\
0.01926 \\
0.02943 \\
0.04423 \\
0.05886\end{array}$ & $\begin{array}{l}1.17681 \\
1.17570 \\
1.17451 \\
1.17277 \\
1.17105\end{array}$ & $\begin{array}{l}1.0144 \\
1.0272 \\
1.0406 \\
1.0597 \\
1.0787\end{array}$ \\
\hline
\end{tabular}

where $\eta$ and $\eta_{0}$ are the viscosities of the solution and solvent, respectively, $\eta_{\mathrm{r}}$ is the relative viscosity and $C$ is the molar concentration.

The plots of $\left(\eta_{\mathrm{r}}-1\right) / \sqrt{C}$ against $\sqrt{C}$ (Fig. 1) for the electrolytes are linear, and the experimental $A$ values at 25,35 , and $45^{\circ} \mathrm{C}$ have been calculated using the least squares method. The $A$ coefficients were also calculated at $25^{\circ} \mathrm{C}$ from the physical properties of the solvent and the limiting ionic equivalent conductance by using the Falkenhagen and Vernon equation [5]

$$
A_{\text {theo }}=\frac{0.2577 \Lambda_{0}}{\eta_{0}(\varepsilon T)^{1 / 2} \lambda_{0}^{+} \lambda_{0}^{-}}\left[1-0.6863\left(\frac{\lambda_{0}^{+}-\lambda_{0}^{-}}{\Lambda_{0}}\right)^{2}\right] \text {. }
$$

The conductance data required in these calculations were taken from our earlier work [1]. The $A_{\text {theo }}$ coeffi- 


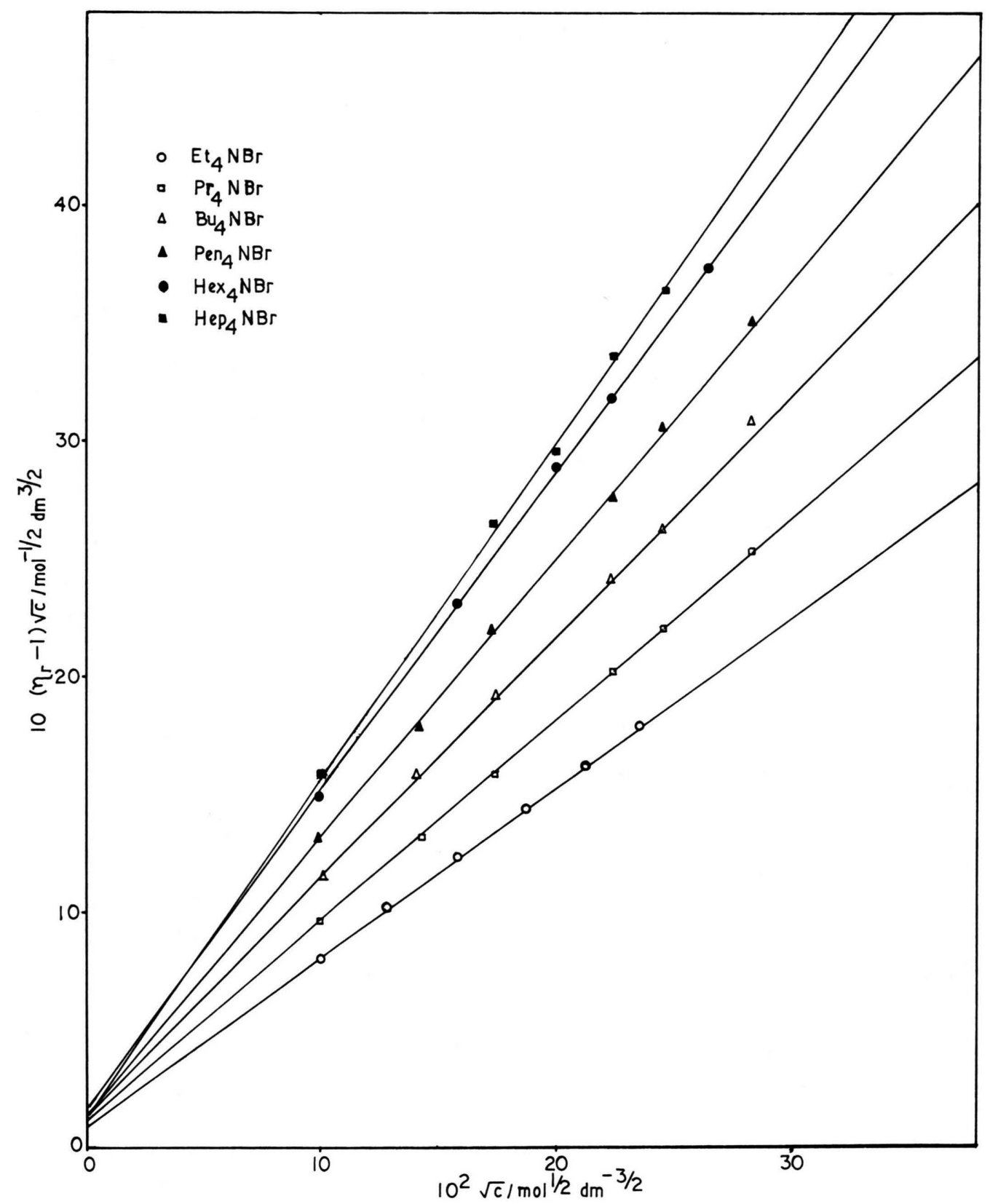

Fig. 1. Representative plot of $\left(\eta_{\mathrm{r}}-1\right) / \sqrt{c}$ against $\sqrt{c}$ for some electrolytes in PC at $25^{\circ} \mathrm{C}$.

cients obtained from (2) along with the experimental $A$ values are reported in Table 3.

Viscosity $B$ coefficients obtained at various temperatures using the least squares method are presented in Table 4.
Activation Parameters for the Viscous Flow

The viscosity data have also been analysed on the basis of the transition-state treatment of the relative viscosity of electrolyte solutions as suggested by 
Feakins et al. [6]:

$$
B=\frac{\overline{V_{1}^{0}}-\overline{V_{2}^{0}}}{1000}+\frac{\overline{V_{1}^{0}}}{1000}\left(\frac{\Delta \mu_{2}^{0 \neq}-\Delta \mu_{1}^{0 \neq}}{R T}\right) .
$$

In the above equation $\overline{V_{1}^{0}}$ and $\overline{V_{2}^{0}}$ are the partial molar volumes of solvent and solute, respectively. $\Delta \mu_{2}^{0 \neq}$, the contribution per mole of solute to the freeenergy of activation for viscous flow of the solution, has been determined from the above relationship as reported in Table $4 . \Delta \mu_{1}^{0 \neq}$, the free energy of activation per mole of the pure solvent is given by the equation [7]

$$
\Delta \mu_{1}^{0 \neq}=\Delta G_{1}^{0 \neq}=R T \ln \left(\eta_{0} \overline{V_{1}^{0}} / h N\right),
$$

$N=$ Avogadro's number.

\section{Discussion}

The $A$ coefficients shown in Table 3 are found to be small and positive for all the electrolytes, and the experimental results at $25^{\circ} \mathrm{C}$ agree well with the theoretical one within $20 \%$ for the quarternary ammonium salts. This error in the small $A$ values corresponds to the

Table 3. Theoretical $A$ values and experimental $A$ coeffi-

\begin{tabular}{|c|c|c|c|c|}
\hline \multirow[t]{2}{*}{ Salts } & \multirow[t]{2}{*}{$A_{\text {theo }}$} & \multicolumn{3}{|c|}{$A_{\text {obs }}$} \\
\hline & & $25^{\circ} \mathrm{C}$ & $35^{\circ} \mathrm{C}$ & $45^{\circ} \mathrm{C}$ \\
\hline $\mathrm{Et}_{4} \mathrm{NBr}$ & 0.0102 & 0.0082 & 0.0089 & 0.0066 \\
\hline $\mathrm{Pr}_{4} \mathrm{NBr}$ & 0.0108 & 0.0104 & 0.0080 & 0.0080 \\
\hline $\mathrm{Bu}_{4} \mathrm{NBr}$ & 0.0113 & 0.0093 & 0.0109 & 0.0083 \\
\hline $\mathrm{Pen}_{4} \mathrm{NBr}$ & 0.0130 & 0.0106 & 0.0117 & 0.0138 \\
\hline $\mathrm{Hex}_{4} \mathrm{NBr}$ & 0.0136 & 0.0079 & 0.0125 & 0.0189 \\
\hline $\mathrm{Hep}_{4} \mathrm{NBr}$ & 0.0147 & 0.0115 & 0.0128 & 0.0139 \\
\hline $\mathrm{LiBF}_{4}$ & 0.0114 & 0.0072 & 0.0095 & 0.0152 \\
\hline $\mathrm{Bu}_{4} \mathrm{NBPh}_{4}$ & 0.0176 & 0.0135 & 0.0198 & 0.0237 \\
\hline
\end{tabular}
cients, $A_{\text {obs }} /\left(\mathrm{dm}^{3 / 2} \mathrm{~mol}^{-1 / 2}\right)$ at 25,35 and $45^{\circ} \mathrm{C}$. experimental uncertainty of $0.05 \%$ of the viscosity data. Similar results have been found in other systems [8].

The viscosity $B$ coefficients (Table 4 ) are large, positive and increase in PC as we go from tetraethylammonium to tetraheptylammonium bromide. Our reported viscosity $B$ coefficient $(1.043)$ at $25^{\circ} \mathrm{C}$ for $\mathrm{Bu}_{4} \mathrm{NBr}$ is slightly greater than the $B$ value $(0.960)$

Table 5. Ionic $B$ coefficients, $B_{ \pm} /\left(\mathrm{dm}^{2} \mathrm{~mol}^{-1}\right)$ and ionic

\begin{tabular}{|c|c|c|c|c|c|c|}
\hline \multirow[t]{2}{*}{ Ion } & \multicolumn{2}{|l|}{$25^{\circ} \mathrm{C}$} & \multicolumn{2}{|l|}{$35^{\circ} \mathrm{C}$} & \multicolumn{2}{|l|}{$45^{\circ} \mathrm{C}$} \\
\hline & $B_{ \pm}$ & $\Delta \mu_{2}^{0 \neq}$ & $B_{ \pm}$ & $\Delta \mu_{2}^{0 \neq}$ & $B_{ \pm}$ & $\Delta \mu_{2}^{0 \neq}$ \\
\hline $\mathrm{Et}_{4} \mathrm{~N}^{+}$ & 0.258 & 16.22 & 0.246 & 15.57 & 0.242 & 15.13 \\
\hline $\mathrm{Pr}_{4}{ }_{4} \mathrm{~N}^{+}$ & 0.397 & 22.36 & 0.382 & 21.97 & 0.377 & 21.80 \\
\hline $\mathrm{Bu}_{4} \mathrm{~N}^{+}$ & 0.585 & 29.97 & 0.577 & 30.60 & 0.564 & 30.97 \\
\hline $\mathrm{Pen}_{4} \mathrm{~N}^{+}$ & 0.736 & 36.25 & 0.717 & 38.75 & 0.695 & 40.92 \\
\hline $\mathrm{Hex}_{4} \mathrm{~N}^{+}$ & 0.927 & 44.09 & 0.911 & 45.69 & 0.904 & 47.97 \\
\hline $\mathrm{Hep}_{4} \mathrm{~N}^{+}$ & 0.996 & 48.11 & 0.988 & 49.44 & 0.980 & 50.90 \\
\hline $\mathrm{Li}^{f}$ & 0.792 & - & - & - & - & - \\
\hline $\mathrm{Br}^{-}$ & 0.458 & 22.34 & 0.428 & 22.29 & 0.411 & 22.44 \\
\hline $\mathrm{BF}_{4}^{-}$ & 0.411 & - & - & - & - & - \\
\hline $\mathrm{BPh}_{4}^{-}$ & 0.717 & 36.71 & 0.706 & 37.48 & 0.692 & 37.95 \\
\hline
\end{tabular}
$\Delta \mu_{2}^{0 \neq} /\left(\mathrm{kJ} \mathrm{mol}^{-1}\right)$ values in PC at different temperatures.

Table 6. Ionic radii, $R_{ \pm} /(\AA)$ and solvation number, $n_{\mathrm{s}}$, of ions in $\mathrm{PC}$ at $25^{\circ} \mathrm{C}$.

\begin{tabular}{llllr}
\hline Ion & $\begin{array}{l}r_{\mathrm{c}} \\
(\AA)\end{array}$ & $\begin{array}{l}r_{\mathrm{s}} \\
(\AA)\end{array}$ & $\begin{array}{l}R_{ \pm} \\
(\AA)\end{array}$ & $n_{\mathrm{s}}$ \\
\hline $\mathrm{Et}_{4} \mathrm{~N}^{+}$ & 4.00 & 2.82 & 3.45 & -1.94 \\
$\mathrm{Pr}_{4} \mathrm{~N}^{+}$ & 4.52 & 3.21 & 3.98 & -2.68 \\
$\mathrm{Bu}_{4} \mathrm{~N}^{+}$ & 4.94 & 3.49 & 4.53 & -3.18 \\
$\mathrm{Pen}_{4} \mathrm{~N}^{+}$ & 5.29 & 4.81 & 4.89 & -3.82 \\
$\mathrm{Hex}_{4} \mathrm{~N}^{+}$ & 5.59 & 5.38 & 5.28 & -4.24 \\
$\mathrm{Hep}_{4} \mathrm{~N}^{+}$ & 5.88 & 6.39 & 5.41 & -5.32 \\
$\mathrm{Li}^{+}$ & 0.60 & 3.72 & 5.01 & 3.71 \\
$\mathrm{Br}^{-}$ & 1.95 & 1.81 & 4.17 & 1.78 \\
$\mathrm{BF}_{4}^{-}$ & 2.01 & 1.68 & 4.02 & 1.53 \\
$\mathrm{BPh}_{4}^{-}$ & 4.20 & 3.76 & 4.84 & -0.28 \\
\hline
\end{tabular}

\begin{tabular}{|c|c|c|c|c|c|c|}
\hline \multirow[t]{2}{*}{ Salts } & \multicolumn{2}{|c|}{$25^{\circ} \mathrm{C}$} & \multicolumn{2}{|c|}{$35^{\circ} \mathrm{C}$} & \multicolumn{2}{|c|}{$45^{\circ} \mathrm{C}$} \\
\hline & $B$ & $\Delta \mu_{2}^{0 \neq}$ & $B$ & $\Delta \mu_{2}^{0 \neq}$ & $B$ & $\Delta \mu_{2}^{0 \neq}$ \\
\hline $\mathrm{Et}_{4} \mathrm{NBr}$ & $0.716 \pm 0.004$ & 38.56 & $0.674 \pm 0.009$ & 37.86 & $0.653 \pm 0.003$ & 37.57 \\
\hline $\mathrm{Pr}_{4} \mathrm{NBr}$ & $0.855 \pm 0.001$ & 44.70 & $0.810 \pm 0.007$ & 44.26 & $0.788 \pm 0.001$ & 44.24 \\
\hline $\mathrm{Bu}_{4} \mathrm{NBr}$ & $1.043 \pm 0.012$ & 52.31 & $1.005 \pm 0.001$ & 52.89 & $0.975 \pm 0.007$ & 53.41 \\
\hline $\mathrm{Pen}_{4} \mathrm{NBr}$ & $1.194 \pm 0.007$ & 58.59 & $1.145 \pm 0.010$ & 61.04 & $1.106 \pm 0.006$ & 63.36 \\
\hline $\mathrm{Hex}_{4} \mathrm{NBr}$ & $1.385 \pm 0.019$ & 66.43 & $1.339 \pm 0.002$ & 67.98 & $1.315 \pm 0.008$ & 70.41 \\
\hline $\mathrm{Hep}_{4} \mathrm{NBr}$ & $1.454 \pm 0.009$ & 70.45 & $1.416 \pm 0.010$ & 71.73 & $1.391 \pm 0.015$ & 73.34 \\
\hline $\mathrm{LiBF}_{4}$ & $1.203 \pm 0.036$ & 49.05 & $1.105 \pm 0.032$ & 47.00 & $1.021 \pm 0.006$ & 44.52 \\
\hline $\mathrm{Bu}_{4} \mathrm{NBPh}_{4}$ & $1.302 \pm 0.061$ & 66.68 & $1.283 \pm 0.013$ & 68.08 & $1.256 \pm 0.002$ & 68.92 \\
\hline
\end{tabular}

Table 4. Viscosity $B$ coefficients, $B /\left(\mathrm{dm}^{3} \mathrm{~mol}^{-1}\right)$ and $\Delta \mu_{2}^{0 \neq} /\left(\mathrm{kJ} \mathrm{mol}^{-1}\right)$ values in propylene carbonate at different temperatures. 
reported previously by Boden et al. [9] by simply plotting the relative viscosity against the concentration in the Jones-Dole equation. The $B$ value of lithium tetrafluoroborate is found to be approximately equal to that of $\mathrm{Pen}_{4} \mathrm{NBr}$. The $B$ coefficients show moderate temperature dependence and the values decrease with increase of temperature as observed earlier in some dipolar aprotic solvents like acetonitrile $[8,10]$, sulfolane [11] and DMSO [2, 12]. Further, from Table 4 we see that, although $\mathrm{d} B / \mathrm{d} T$ is small, it is negative in sign for all the electrolytes, indicating that they behave as structure makers in this solvent medium.

The ionic $B$ values were calculated using $\mathrm{Bu}_{4} \mathrm{NBPh}_{4}$ as the "reference electrolyte" $[13,14]$ :

$$
\begin{aligned}
& B\left(\mathrm{Bu}_{4} \mathrm{NBPh}_{4}\right)=B\left(\mathrm{Bu}_{4} \mathrm{~N}^{+}\right)+B\left(\mathrm{BPh}_{4}^{-}\right), \\
& B_{\mathrm{Ph}_{4} \mathrm{~B}^{-}} / B_{\mathrm{Bu}_{4} \mathrm{~N}^{+}}=(5.35 / 5.00)^{3} .
\end{aligned}
$$

The ionic $B$ values along with the ionic $\Delta \mu_{2}^{0 \neq}$ data obtained from the above relationships are given in Table 5. Table 5 shows that the viscosity $B$ coefficients for cations and anions are all positive and also very high. The ionic $B$ value for $\mathrm{Li}^{+}$at $25^{\circ} \mathrm{C}$ was calculated from the reported viscosity $B$ value of $\mathrm{LiBr}$ [9] in $\mathrm{PC}$ assuming additivity. The observed order of the $B_{+}$ coefficients, $\mathrm{Hep}_{4} \mathrm{~N}^{+}>\mathrm{Hex}_{4} \mathrm{~N}^{+}>\mathrm{Pen}_{4} \mathrm{~N}^{+}>\mathrm{Bu}_{4} \mathrm{~N}^{+}$ $>\mathrm{Pr}_{4} \mathrm{~N}^{+}>\mathrm{Et}_{4} \mathrm{~N}^{+}$, shows that the obstruction of the solvent viscous flow increases with decrease of the ion charge density and with decrease of the size of the hydrodynamic entity by solvation. For anions, the $B$-values are seen to be in the order $\mathrm{BPh}_{4}^{-}>\mathrm{Br}^{-}>\mathrm{BF}_{4}^{-}$. The $\mathrm{d} B_{ \pm} / \mathrm{d} T$ values of the cations and anions are generally found to be negative (structure-making). This behaviour of tetraalkylammonium ions in PC, arising mainly from the interactions of alkyl groups and solvent molecules, is similar to that observed in sulfolane by Sacco and coworkers $[11,15]$.

The values of $\Delta \mu_{2}^{0 \neq}$ for tetraalkylammonium ions decrease in the order $\mathrm{Hep}_{4} \mathrm{~N}^{+}>\mathrm{Hex}_{4} \mathrm{~N}^{+}>\mathrm{Pen}_{4} \mathrm{~N}^{+}$ $>\mathrm{Bu}_{4} \mathrm{~N}^{+}>\mathrm{Pr}_{4} \mathrm{~N}^{+}>\mathrm{Et}_{4} \mathrm{~N}^{+}$, and for anions $\mathrm{BPh}_{4}^{-}$ $>\mathrm{Br}^{-}$. However, these values are found to be positive, and thus the formation of the transition-state is less favourable in the presence of these ions.

Ionic $B_{ \pm}$coefficients have also been analysed on the basis of Einstein's equation [16]

$$
B_{ \pm}=2.5 \frac{4}{3} \pi \frac{R_{ \pm}^{3} N}{1000}
$$

where $R_{ \pm}$(in $\AA$ ) is the radius of the ion assumed to be a rigid sphere moving in a continuum and 2.5 is the shape factor for a sphere. The number of solvent molecules $\left(n_{\mathrm{s}}\right)$ bound to the ion in the primary sphere of solvation can be calculated by combination of the Jones-Dole equation with that of Einstein [17]

$$
B_{ \pm}=\frac{2.5}{1000}\left(V_{i}+n_{\mathrm{s}} V_{\mathrm{s}}\right)
$$

where $V_{i}$ represents the bare ion molar volume and is related to the crystallographic radius $\left(r_{\mathrm{c}}\right)$ of the ion. $V_{\mathrm{s}}$ is the solvent molar volume. The values of $R_{ \pm}$and $n_{\mathrm{s}}$ are shown in Table 6.

The $R_{ \pm}$values for tetraalkylammonium ions are found to be in reasonable agreement with the Stokes and crystallographic radii. The results indicate that these ions are scarcely solvated in PC and behave as spherical entities. However, the $R_{ \pm}$value of $\mathrm{Li}^{+}$is much higher than its crystallographic radius, indicating that it is highly solvated in PC by ion-dipole interactions. Similar results have been obtained by conductometric measurements [1], which shows that $\mathrm{Li}^{+}$is highly solvated in this medium. Thus, it appears that the large size of the $\mathrm{R}_{4} \mathrm{~N}^{+}$ions, their low charge density and the high dielectric constant of $\mathrm{PC}$ render these ions to be free, unassociated and almost unsolvated in this medium.

\section{Acknowledgement}

PKM thanks the University of North Bengal for the award of a junior research fellowship. 
[1] P. K. Muhuri and D. K. Hazra, J. Chem. Soc. Faraday Trans. 87, 3511 (1991).

[2] S. Das, D. K. Hazra, and S. C. Lahiri, Z. Phys. Chem. (N.F.) 138, 185 (1983).

[3] D. Nandi, S. Das, and D. K. Hazra, J. Chem. Soc. Faraday Trans. I 85, 1531 (1989).

[4] G. Jones and M. Dole, J. Amer. Chem. Soc. 51, 2950 (1929).

[5] H. Falkenhagen and E. L. Vernon, Phys. Z. 33, 140 (1932); Philos. Mag. 14, 537 (1932).

[6] D. Feakins, D. J. Freemantle, and K. G. Lawrence, J. Chem. Soc. Faraday Trans. I 70, 795 (1974).

[7] S. Glasstone, K. J. Laidler, and M. Eyring, The Theory of Rate Processes, McGraw-Hill, New York 1941, p. 477.

[8] K. Ibuki and M. Nakahara, J. Phys. Chem. 94, 8370 (1990).
[9] L. M. Mukherjee and D. P. Boden, J. Phys. Chem. 73, 3965 (1969).

[10] D. S. Gill and M. S. Chauhan, Z. Phys. Chem. 140, 149 (1984).

[11] A. Sacco, G. Petrella, and M. Castagnolo, J. Phys. Chem. 80, 749 (1976).

[12] R. T. M. Bicknell, K. G. Lawrence, and D. Feakins, J. Chem. Soc. Faraday Trans. I 76, 637 (1980).

[13] D. F. Tuan and R. M. Fuoss, J. Phys. Chem. 67, 1343 (1963).

[14] D. S. Gill and M. B. Sekhri, J. Chem. Soc. Faraday Trans. I 78, 475 (1982).

[15] A. Sacco, G. Petrella, M. D. Monica, and M. Castagnolo, J. Chem. Soc. Faraday Trans. I 75, 2325 (1979).

[16] A. Einstein, Ann. Phys. 19, 289 (1906).

[17] D. Feakins and K. G. Lawrence, J. Chem. Soc. A 212 (1966). 